\title{
Update on immunopathogenesis and immunotherapy in multiple sclerosis
}

This article was published in the following Dove Press journal:

ImmunoTargets and Therapy

25 April 2013

Number of times this article has been viewed

\author{
Rebecca C Selter ${ }^{\prime}$ \\ Bernhard Hemmer ${ }^{1-3}$ \\ 'Department of Neurology, Klinikum \\ Rechts der Isar, Technische Universität \\ München, Munich, Germany; ${ }^{2}$ Munich \\ Cluster for Systems Neurology \\ (SyNergy), Munich, Germany; \\ ${ }^{3}$ Competence Network on Multiple \\ Sklerosis, Munich, Germany
}

\begin{abstract}
Multiple sclerosis is a chronic inflammatory demyelinating disease of the central nervous system. Both genetic and environmental factors are believed to contribute to the pathogenesis of the disease. Histopathological findings suggest that multiple sclerosis is an immune-mediated disease, involving both the cellular and humoral immune systems. Within the last 20 years, several disease-modifying therapies for the treatment of multiple sclerosis were established. Moreover, promising new substances are currently being tested in clinical trials and will likely broaden the therapeutic opportunities available within the upcoming years.
\end{abstract}

Keywords: multiple sclerosis, immunopathogenesis, disease-modifying therapy

\section{Immunopathogenesis of multiple sclerosis}

Multiple sclerosis (MS) is a chronic inflammatory demyelinating disease of the central nervous system (CNS), affecting approximately 1.3 million worldwide. ${ }^{1}$ The majority of MS patients will develop significant disability over time. Although the pathogenesis has been the focus of MS research for several decades, the mechanisms leading to evolution and progression of the disease are still uncertain. Several lines of evidence point to an autoimmune pathogenesis, with both genetic and environmental factors contributing to disease susceptibility. ${ }^{2-4}$ Large-scale genetic studies in MS have revealed more than 50 gene loci associated with MS, with the HLADRB1*1501 allele being the most important. ${ }^{5}$ Interestingly, there is a great overlap with loci observed in other autoimmune diseases, such as diabetes and rheumatoid arthritis. Among the possible environmental factors, infection with Epstein Barr virus and low vitamin D levels seem to be the most important contributors to susceptibility. ${ }^{3,4,6}$ Other factors, such as the gut microbiome, have been discussed as possible susceptibility factors based on findings in experimental animal models. ${ }^{7,8}$

A large body of evidence suggests that MS is an autoimmune disease. ${ }^{9} \mathrm{CNS}$ antigens seem to be the likely targets of the autoimmune response. It is conceivable that in genetically susceptible individuals, an infection or release of CNS proteins into the periphery may trigger loss of self-tolerance towards CNS proteins, probably by activation of myelin-reactive T cells. ${ }^{10}$ Viral infections can probably cause bystander activation of T cells in an immunostimulatory context. ${ }^{11}$ Moreover, release of autoantigens due to cellular damage by a viral agent can lead to activation of autoreactive $T$ cells due to cross-reactivity between viral antigens and CNS antigens, a mechanism known as molecular mimicry. ${ }^{10,12,13}$ After migration into the CNS, autoreactive $\mathrm{T}$ cells may become reactivated by antigen-presenting cells presenting CNS autoantigens on major
Correspondence: Bernhard Hemmer Department of Neurology, Klinikum Rechts der Isar, Technische Universität München, Ismaninger Strasse 22, Munich 81675, Germany

Tel +498941404600

Fax+49894140 768I

Email hemmer@Irz.tum.de 
histocompatibility complex molecules to the invading T cells (Figure 1).

Histopathologically, MS lesions are characterized by inflammatory infiltrates consisting of activated $\mathrm{T}$ cells, B cells, plasma cells, and macrophages. Whereas CD4+ $\mathrm{T}$ cells are mainly found in the perivascular spaces and meninges, CD8+ $\mathrm{T}$ cells are located in the parenchyma of MS lesions. ${ }^{14}$ In MS lesions, profound demyelination, axonal damage, astrogliosis, and remyelination is observed. ${ }^{15-19}$ Besides, deposits of complement proteins and immunoglobulins are seen. Several proinflammatory cytokines and matrix metalloproteinases are active in MS lesions. ${ }^{13,14,16,20}$

In the pathogenesis of MS, CD4+ T cells are believed to release cytokines and immune mediators, which lead to attraction of macrophages and further release of proinflammatory cytokines. CD4+ T cells require for their activation an interaction with major histocompatibility complex class II expressing cells, such as dendritic cells, macrophages, or B cells. Animal experiments suggest that T-helper (Th) 1 cells, which release interferon-gamma and Th17 cells, which secrete Th17, play a key role in inflammation within the CNS. In contrast, Th2 cells, characterized by secretion of interleukins 4, 5, and 10, and regulatory $\mathrm{T}$ cells expressing Foxp3, counter-regulate encephalitogenic Th1 and Th17 responses. ${ }^{21}$ Moreover, some
T cells may not only cause harm to CNS tissue, but also prime regeneration of MS lesions. ${ }^{22}$

CD8+ T cells also seem to be involved in the pathogenesis. In contrast with CD4+ T cells, $C D 8+T$ cells can directly interact with and damage major histocompatibility complex I/antigenexpressing cells, such as neurons and oligodendrocytes. ${ }^{23}$

As a consequence of the release of proinflammatory cytokines and cellular damage, microglia are activated and monocytes and macrophages are recruited into the lesion. Further CNS antigens are released and presented to potentially autoreactive T cells. Epitope spreading may lead to a broadened autoimmune response involving further autoantigens. ${ }^{24}$

Alongside T cells, B cells are believed to play an important role in the pathogenesis of MS. B cells are important antigenpresenting cells in the peripheral immune system and possibly also in the CNS. They can capture soluble proteins by their specific B cell receptor, process and present peptide antigens bound to major histocompatibility complex class II molecules to autoreactive T cells. Plasmablasts and plasma cells can release immunoglobulins which probably bind to autoantigens on glial cells..$^{25-27}$ Possible mechanisms of antibody-mediated pathogenicity include complement activation or antibodydependent cellular cytotoxicity. ${ }^{26,28}$ Indeed, the complement protein $\mathrm{C} 9$ neo, which is part of the terminal lytic membrane attack complex, and immunoglobulin $\mathrm{G}$ deposits have been detected at the border of MS plaques. ${ }^{20,26}$ Moreover, the

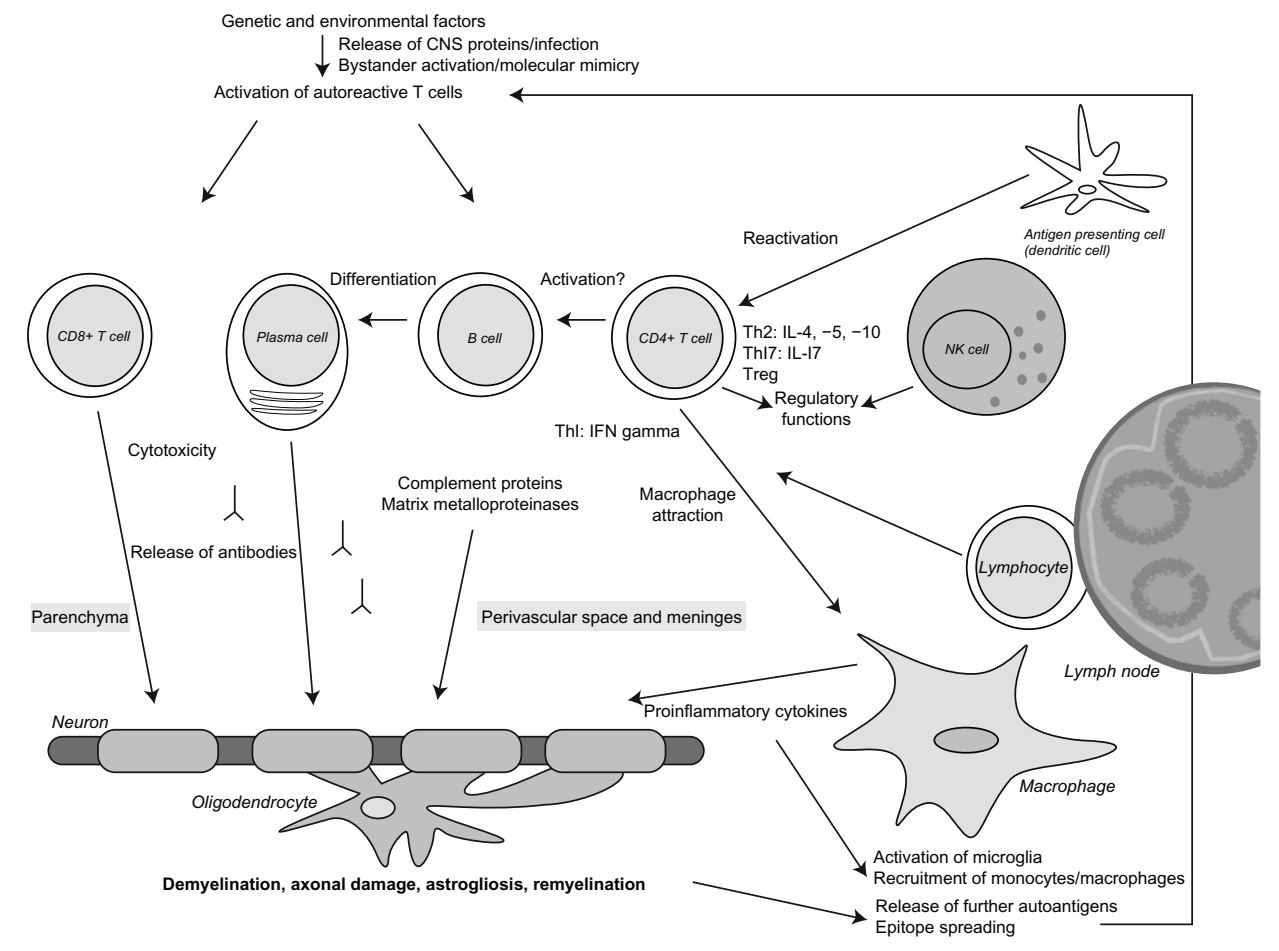

Figure I Immunopathogenesis of multiple sclerosis.

Abbreviations: Treg, regulatory T cell; NK cell, natural killer cell; IL, interleukin. 
presence of intrathecal immunoglobulin G synthesis and detection of clonally expanded $\mathrm{B}$ cells in the cerebrospinal fluid and brain lesions of MS patients argue for a substantial role of B cells in MS. ${ }^{29}$ The clinical relevance of these findings is supported by a clinical trial demonstrating that patients with lesions characterized by complement and immunoglobulin $\mathrm{G}$ deposition respond exceptionally well to therapeutic plasma exchange. ${ }^{30}$ More recently, the role of cortical lesions has come more into the focus of MS research. In contrast with white matter lesions, cortical lesions seem to be mainly driven by meningeal inflammatory infiltrates and soluble factors from the cerebrospinal fluid (CSF). ${ }^{31,32}$ Therefore, histopathological findings suggest a role of both the cellular and humoral immune systems in the pathogenesis of MS.

\section{Disease-modifying therapies in multiple sclerosis}

During the past 20 years, several disease-modifying substances have been developed for treatment of MS. Figure 2 and Table 1 summarize established therapies and drugs currently evaluated in clinical trials.

\section{Immunomodulatory and immunosuppressive therapies}

This group of drugs aims to suppress or alter immune responses in the periphery. The mechanisms are rather nonselective and affect a broad range of immune cells.

\section{Interferon beta}

The first immunomodulatory drug approved for the treatment of relapsing-remitting forms of MS was interferon-beta $1 \mathrm{~b}$ in 1993. The pivotal trial showed a significant reduction in relapse rate and the number of active lesions on magnetic resonance imaging. ${ }^{33}$ Within the following years, several formulations of interferon-beta $1 \mathrm{a}$ and $1 \mathrm{~b}$ came onto the market. In secondary progressive MS, interferon-beta $1 \mathrm{~b}$ delayed disease progression in the European trial but failed in the US trial. ${ }^{34,35}$ Detailed analysis of the trials suggested that interferon-beta $1 \mathrm{~b}$ is active in secondary progressive MS, as long as relapse activity is present. ${ }^{36}$ Accordingly, the drug was approved for treatment of secondary progressive MS with ongoing relapse activity in Europe. Moreover, in patients with clinically isolated syndrome, conversion to clinically definite MS was significantly delayed by early treatment with interferon-beta. ${ }^{37,38}$ The mechanism by which interferon-beta decreases inflammatory disease activity in MS is still unknown. Different mechanisms are likely to be important, such as its effects on cytokines, chemokines, and metalloproteinases, and also the modulation of lymphocyte activation and migration and proliferation of regulatory T cells. . $^{39,40}$

\section{Glatiramer acetate}

Glatiramer acetate is an amino acid copolymer consisting of L-alanine, L-lysine, L-glutamic acid, and L-tyrosine,

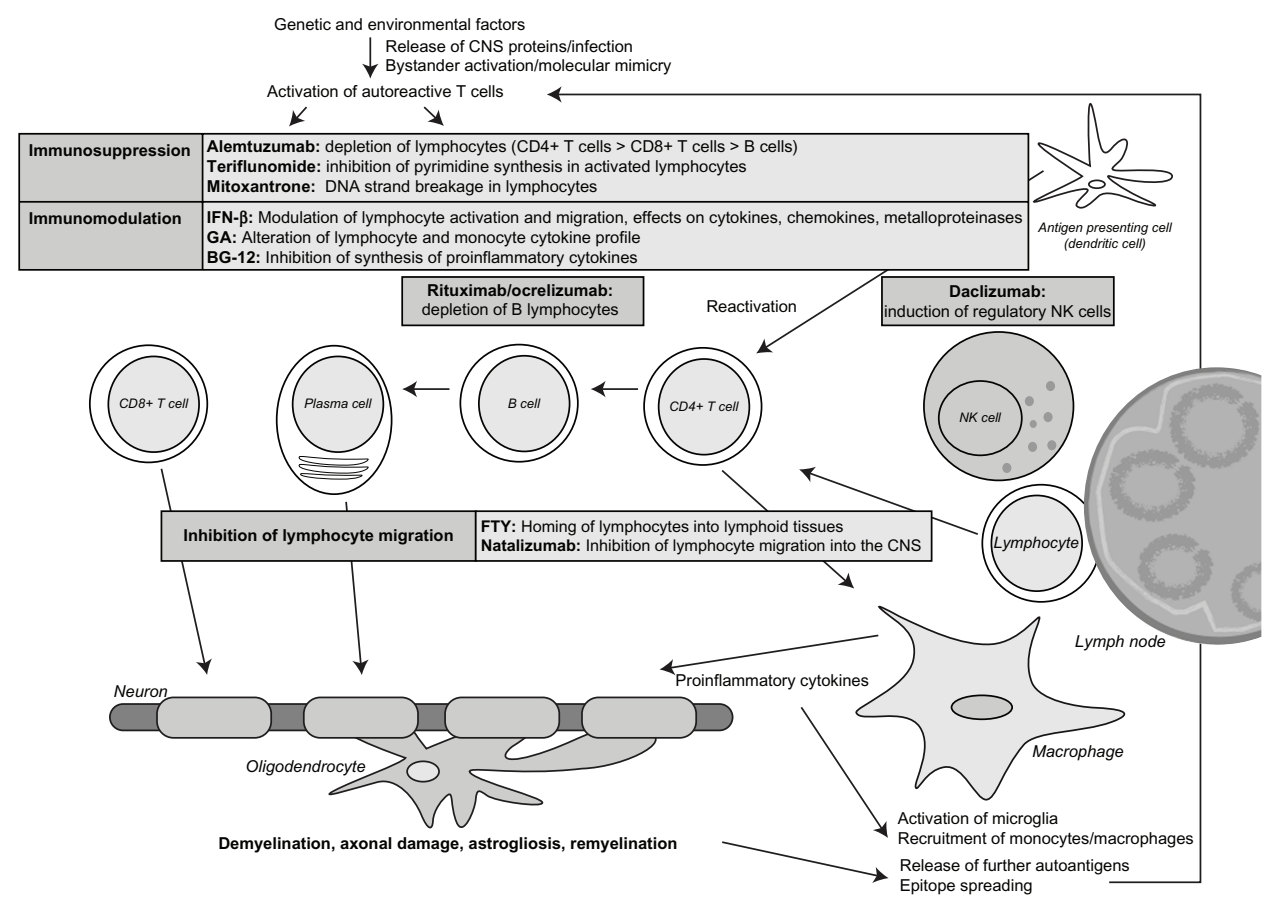

Figure 2 Established and emerging multiple sclerosis therapies.

Abbreviations: IFN- $\beta$, interferon beta; GA, glatiramer acetate; BG-I2, dimethyl fumarate; FTY, fingolimod; NK cell, natural killer cell. 
Table I Summary of application, assumed mode of action, and current status of drug development

\begin{tabular}{|c|c|c|c|}
\hline Drug (brand name) & Administration & (Assumed) mode of action & Status of development \\
\hline $\begin{array}{l}\text { Interferon beta-la } \\
\text { (Avonex }{ }^{\circledast}[\text { Biogen Idec }] \text { ) }\end{array}$ & $\begin{array}{l}\text { Intramuscularly once } \\
\text { a week }\end{array}$ & $\begin{array}{l}\text { Effects on cytokines, chemokines, and } \\
\text { metalloproteinases, modulation of lymphocyte }\end{array}$ & Approved (CIS, RRMS) \\
\hline $\begin{array}{l}\text { Interferon beta-lb (Betaferon }{ }^{\circledast}, \\
\text { [Bayer]), } \\
\text { Betaseron }^{\circledast},\left[\text { Bayer], Extavia }{ }^{\circledR}\right. \\
{[\text { Novartis]) }}\end{array}$ & $\begin{array}{l}\text { Subcutaneously every } \\
\text { other day }\end{array}$ & $\begin{array}{l}\text { activation and migration, proliferation of } \\
\text { regulatory } T \text { cells }\end{array}$ & $\begin{array}{l}\text { Approved (CIS, RRMS; and } \\
\text { SPMS with ongoing relapse } \\
\text { activity in Europe) }\end{array}$ \\
\hline $\begin{array}{l}\text { Interferon-beta la } \\
\text { (Rebif }{ }^{\circledast} \text { [Merck Serono]) }\end{array}$ & $\begin{array}{l}\text { Subcutaneously three } \\
\text { times a week }\end{array}$ & & \\
\hline $\begin{array}{l}\text { Glatiramer acetate } \\
\left(\text { Copaxone }{ }^{\circledR}[\text { Teva }]\right)\end{array}$ & $\begin{array}{l}\text { Subcutaneously once } \\
\text { daily }\end{array}$ & $\begin{array}{l}\text { Alteration of the cytokine profile of } T \text { cells and } \\
\text { monocytes, induction of regulatory } T \text { cells, } \\
\text { induction of neurotrophic factors in immune cells }\end{array}$ & Approved (CIS, RRMS) \\
\hline $\begin{array}{l}\text { Mitoxantrone } \\
\text { (Ralenova }{ }^{\circledR} \text { [MEDA Pharma]) }\end{array}$ & $\begin{array}{l}\text { Intravenously every } \\
\text { three months }\end{array}$ & DNA strand breakage and inhibition of DNA repair & $\begin{array}{l}\text { Approved (highly } \\
\text { progressive SPMS, third line } \\
\text { in highly active RRMS) }\end{array}$ \\
\hline $\begin{array}{l}\text { Natalizumab } \\
\left(\text { Tysabri }{ }^{\circledast}[\text { Biogen Idec }]\right)\end{array}$ & $\begin{array}{l}\text { Intravenously every } \\
4 \text { weeks }\end{array}$ & $\begin{array}{l}\text { Inhibition of lymphocyte migration across the } \\
\text { blood-brain barrier and into the CNS }\end{array}$ & $\begin{array}{l}\text { Approved (highly active or } \\
\text { breakthrough RRMS) }\end{array}$ \\
\hline $\begin{array}{l}\text { Fingolimod } \\
\text { (Gilenya }{ }^{\circledR}[\text { Novartis }] \text { ) }\end{array}$ & Orally once daily & $\begin{array}{l}\text { Inhibition of lymphocyte egress from secondary } \\
\text { lymphoid tissue }\end{array}$ & $\begin{array}{l}\text { Approved (highly active } \\
\text { RRMS in Europe, baseline } \\
\text { therapy of RRMS in the US) }\end{array}$ \\
\hline $\begin{array}{l}\text { Alemtuzumab } \\
\text { (Campath IH } \mathrm{H}^{\circledR}[\text { Genzyme }] \text { ) }\end{array}$ & Intravenously & $\begin{array}{l}\text { Depletion of lymphocytes, monocytes, eosinophils, } \\
\text { thymocytes }\end{array}$ & Phase III (RRMS) completed \\
\hline $\begin{array}{l}\text { Rituximab } \\
\text { (MabThera }{ }^{\circledR} \text { [Hoffmann-La Roche], } \\
\text { Rituxan }{ }^{\circledR}[\text { Biogen Idec] })\end{array}$ & Intravenously & Depletion of CD20+ B lymphocytes & Phase II (RRMS, PPMS) \\
\hline Ocrelizumab & Intravenously & & Phase III (RRMS, PPMS) \\
\hline 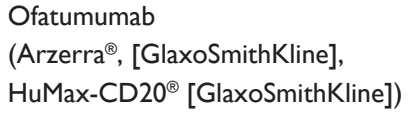 & Intravenously & & Pilot trial (RRMS) \\
\hline Laquinimod & Orally & $\begin{array}{l}\text { Modulation of the Th1/Th2 balance towards a } \\
\text { Th2 response }\end{array}$ & Phase III (RRMS) completed \\
\hline $\begin{array}{l}\text { BG000 I } 2 \\
\text { (Tecfidera }{ }^{\circledR}[\text { Biogen Idec] })\end{array}$ & Orally & $\begin{array}{l}\text { Inhibition of synthesis of proinflammatory } \\
\text { cytokines }\end{array}$ & $\begin{array}{l}\text { Phase III (RRMS) completed/ } \\
\text { approved in the US (RRMS) }\end{array}$ \\
\hline $\begin{array}{l}\text { Teriflunomide } \\
\text { (Aubagio }^{\circledR}[\text { Sanofi Aventis }] \text { ) }\end{array}$ & Orally & $\begin{array}{l}\text { Inhibition of de novo pyrimidine synthesis } \\
\text { in activated lymphocytes }\end{array}$ & $\begin{array}{l}\text { Phase III (RRMS, CIS) } \\
\text { completed/approved in the } \\
\text { US (RRMS) }\end{array}$ \\
\hline $\begin{array}{l}\text { Daclizumab } \\
\text { (Zenapax }{ }^{\circledR}[\text { Hoffmann-La Roche }] \text { ) }\end{array}$ & Intravenously & Inhibition of proliferation of several immune cells & Phase III (RRMS) \\
\hline
\end{tabular}

Abbreviations: RRMS, relapsing-remitting multiple sclerosis; SPMS, secondary progressive multiple sclerosis; PPMS, primary progressive multiple sclerosis; CIS, clinically isolated syndrome; CNS, central nervous system; Th, T-helper.

and was discovered in a model of experimental allergic encephalomyelitis in $1974 .{ }^{41}$ It is believed to inhibit the T cell response towards myelin antigens. ${ }^{42-45}$ Pivotal studies showed a reduction of relapse rate in patients with relapsing-remitting MS by $29 \%$ within two years ${ }^{46}$ and a significant decrease in the total number of enhancing lesions. ${ }^{47}$ Glatiramer acetate was approved for treatment of clinically isolated syndrome in 2009, having been shown to delay conversion to clinically definite MS in the PreCISe Study. ${ }^{48}$ The mechanism by which glatiramer acetate works in MS also remains unclear. It potentially includes alteration of the cytokine profile of $\mathrm{T}$ cells and monocytes, induction of regulatory $\mathrm{T}$ cells, and induction of neurotrophic factors in immune cells. ${ }^{49-51}$

\section{Mitoxantrone}

Mitoxantrone is an anthracenedione which induces DNA strand breakage by intercalation, and also inhibits the DNA repair enzyme, topoisomerase II. In a placebo-controlled Phase III study (MIMS), mitoxantrone reduced disability progression and relapse rates (reduction of relapse rate by $63 \%$ during the first year and $68 \%$ during the second year of treatment compared with placebo) in highly active relapsingremitting and secondary progressive MS. ${ }^{52}$ Mitoxantrone was approved by the US Food and Drug Administration and several European countries in 2000 for worsening relapsingremitting $\mathrm{MS}$, progressive relapsing $\mathrm{MS}$, and secondary progressive MS. Suppression of lymphocytes seems to be its 
main mode of action. Mitoxantrone may cause cardiotoxicity and acute myeloid leukemia at a rate that was not anticipated when the drug was approved. Accordingly, mitoxantrone is primarily used in highly progressive secondary progressive MS and as a third-line therapy in patients with highly active relapsing-remitting MS.

\section{Therapies affecting immune cell migration}

These drugs primarily impact on migration of immune cells within the peripheral immune system or across the blood-brain-barrier.

\section{Natalizumab}

Natalizumab is a humanized monoclonal antibody against $\alpha 4 \beta 1$-integrin (very late activating antigen-4), an adhesion molecule expressed on the surface of activated $\mathrm{T}$ cells and other mononuclear leukocytes, which is essential for entry of leukocytes into the CNS. ${ }^{53}$ Accordingly, migration of lymphocytes is severely impaired in patients treated with natalizumab. In the AFFIRM trial, ${ }^{54}$ natalizumab significantly reduced the relapse rate by almost $70 \%$ and disease progression by more than $50 \%$ in relapsing-remitting MS compared with placebo. Similar effects were observed in the SENTINEL trial, ${ }^{55}$ when natalizumab in combination with interferon-beta 1a was compared with interferon-beta 1a alone. ${ }^{54,55}$ Natalizumab was approved by the Food and Drug Administration in 2006 for relapsing-remitting MS.

However, during the SENTINEL study, two patients died of progressive multifocal leukencephalopathy, an opportunistic brain infection caused by the John Cunningham (JC) virus. Until September 2012, more than 250 natalizumab-treated patients developed progressive multifocal leukencephalopathy. Therefore, natalizumab is only approved as monotherapy for treatment of highly active or breakthrough relapsing-remitting MS. The risk of developing progressive multifocal leukencephalopathy correlates with both treatment duration and JC virus antibody status. In particular, after 24 months of treatment, the risk of progressive multifocal leukencephalopathy increases to approximately 4.6 cases per 1000 per year in JC virus antibody-positive patients without prior immunosuppressive therapy. Moreover, a history of immunosuppressive therapy before initiation of treatment with natalizumab increases the risk of developing progressive multifocal leukencephalopathy. ${ }^{56}$ After discontinuation of therapy, disease activity seems to return to the initial level. ${ }^{57}$

\section{Fingolimod}

In 2010, a new oral drug was approved for the treatment of relapsing-remitting MS, ie, fingolimod (FTY720), a sphingosine 1-phosphate receptor agonist. After phosphorylation in vivo, FTY720-P binds to the sphingosine 1 -phosphate receptor, promoting internalization of the receptor and homing of lymphocytes into lymphoid tissues. ${ }^{58}$ This results in a profound decrease of circulating CD4+ $\mathrm{T}$ cells and B cells in the blood, and to a lesser extent, in the CSF. $^{59}$ Two large Phase III studies have shown significant effects on relapse rate (relative reduction of annualized relapse rate by $54 \%$ at a dose of $0.5 \mathrm{mg}$ daily compared with placebo) and CNS inflammation as measured by magnetic resonance imaging compared with interferon-beta 1a (TRANSFORMS study) ${ }^{60}$ and with placebo (FREEDOMS study) ${ }^{61}$ in relapsing-remitting MS. Relevant side effects include viral infections (herpes viruses), macula edema, skin tumors, elevated liver enzymes, and upper and lower respiratory tract infections. Two patients died in the Phase III trials as a result of viral infections. However, both patients were treated with a high dose of fingolimod, which is no longer used to treat MS. In the US, fingolimod is approved for baseline therapy of relapsing-remitting MS, whereas in Europe it is restricted to patients with highly active disease, comparable with the labeling for natalizumab. More recently, the possible cardiac side effects of the drug have received attention. In December 2011, a patient died suddenly within 24 hours of taking fingolimod for the first time. Therefore, treatment with fingolimod is not recommended without cardiology advice in patients suffering from cardiovascular diseases or taking antiarrhythmic or heart rate-lowering drugs. Cardiac monitoring after the first exposure is mandatory. ${ }^{62,63}$

\section{Emerging therapies}

The drugs described in this section target specific molecules on immune cells and lead to depletion of those cells that express the target molecules.

\section{Alemtuzumab}

Alemtuzumab is a humanized monoclonal antibody against CD52, which is expressed on lymphocytes, monocytes, eosinophils, and thymocytes. ${ }^{64}$ Therefore, alemtuzumab leads to depletion of these cells in peripheral blood. In a Phase II study (CAMMS223), alemtuzumab reduced the relapse rate in relapsing-remitting MS by $74 \%$ compared with interferon-beta. ${ }^{65}$ 
Two Phase III studies (CARE-MS I/II) evaluated the safety and efficacy of alemtuzumab compared with interferon-beta in patients with relapsing-remitting MS. ${ }^{66,67}$ In both studies, a significant reduction in relapse rate compared with interferon-beta 1 a was observed. In one of the trials, a significant reduction in disease progression compared with interferon-beta 1a was also seen. The main side effects of alemtuzumab are autoimmune diseases of the thyroid in up to $19 \%$ of patients, idiopathic thrombocytopenic purpura (1\%), and, rarely, Goodpasture syndrome.

\section{Rituximab/ocrelizumab/ofatumumab}

Rituximab is a chimeric antibody directed against CD20, which is expressed on B cells from the pre-B cell to memory $\mathrm{B}$ cell stage. The antibody depletes all B cells from the peripheral blood and to a certain extent from lymph nodes, although it has no impact on plasma cells in the bone marrow and inflamed tissue. A Phase II trial in relapsing-remitting MS showed a significant reduction of gadolinium-enhancing brain lesions in patients treated with rituximab compared with placebo. ${ }^{68}$ In another Phase II study of patients with primary progressive MS, a reduction in disease progression was observed in a subgroup of young patients with lesion activity on magnetic resonance imaging. ${ }^{69}$

Ocrelizumab is a humanized antibody directed against CD20. In a Phase II study, ocrelizumab significantly reduced the annualized relapse rate (reduction by $80 \%$ in the $600 \mathrm{mg}$ group and $73 \%$ in the $2000 \mathrm{mg}$ group) and the number of gadolinium-enhancing brain lesions in patients with relapsing-remitting MS. ${ }^{70}$ One patient died from systemic inflammatory response syndrome after the first treatment cycle in week 14 of the trial, and a brain autopsy showed signs of hypoxia and brain edema with transcranial herniation. The relationship between treatment and death has remained uncertain. Two Phase III trials are currently recruiting patients with primary progressive MS and relapsing-remitting $\mathrm{MS}$, respectively. ${ }^{71,72} \mathrm{~A}$ small pilot trial with ofatumumab, another CD20-specific antibody, showed significant reduction of magnetic resonance imaging activity in a treatment compared with a placebo group. $^{73}$

\section{New immunosuppressants and immunomodulators}

These drugs impact on immune cells but seem to have fewer side effects than traditional immunosuppressive drugs.

\section{Laquinimod}

The exact mode of action of laquinimod is not fully understood, although a possible mechanism seems to be modulation of the Th1/Th2 balance towards a Th2 response. ${ }^{74}$ In a mouse model of experimental autoimmune encephalomyelitis, laquinimod inhibited the development of disease. ${ }^{75}$ In a Phase II study, laquinimod reduced the number of gadolinium-enhancing lesions in relapsing-remitting MS compared with placebo. ${ }^{76}$ The Phase III ALLEGRO study showed a reduction in the annualized relapse rate by $23 \%$ and of disability progression by $36 \%{ }^{77}$ In the Phase III BRAVO trial, the drug was not superior to interferon-beta $1 \mathrm{a} .{ }^{78}$ Few side effects were observed in the trial and no deaths occurred related to the drug.

\section{BG000I2 (dimethyl fumarate)}

According to in vitro data, BG00012 may exert antiinflammatory effects by inhibiting synthesis of proinflammatory cytokines. ${ }^{79}$ In a Phase II study, BG00012 reduced the number of new gadolinium-enhancing and enlarging lesions, as well as the annualized relapse rate in patients with relapsingremitting MS compared with placebo ${ }^{80}$ Recently, the results of two Phase III trials were published. In both trials, BG00012 significantly reduced relapse rates, compared with placebo, by around $50 \%$. Whereas in the Phase III CONFIRM study, ${ }^{81}$ reduction of disability progression by BG00012 was not significant compared with placebo, the DEFINE study ${ }^{82}$ showed a significant reduction of disability progression by more than $30 \%$. Further, all secondary endpoints were positive. Treatment with BG00012 was associated with gastrointestinal side effects and flushing. No major side effects or deaths related to treatment were observed. ${ }^{81,82}$ Based on the results from the Phase III trials, BG00012 has recently been approved for the treatment of relapsing remitting MS in the US.

\section{Teriflunomide}

Teriflunomide is the active metabolite of leflunomide and acts as an inhibitor of dihydroorotate dehydrogenase, which is essential for pyrimidine synthesis in activated lymphocytes. ${ }^{83}$ In the Phase III TEMSO study, teriflunomide significantly reduced the annualized relapse rate in relapsing-remitting MS by $31 \%$ compared with placebo. ${ }^{84}$ The TOWER trial in relapsing-remitting MS (teriflunomide versus placebo) showed similar results, with a significant decrease in relapse rates and confirmed progression in patients receiving teriflunomide at $14 \mathrm{mg}$ daily compared with placebo. ${ }^{85}$ The ongoing Phase III TENERE trial is comparing the efficacy of 
teriflunomide with that of interferon-beta 1a. ${ }^{86,87}$ Moreover, the Phase III TOPIC study is currently recruiting patients with clinically isolated syndrome. ${ }^{88}$ No major side effects were observed in the clinical trials. Based on two positive Phase III trials, teriflunomide has been approved for the treatment of MS in the US and awaits approval in Europe.

\section{Daclizumab}

Daclizumab is a monoclonal immunoglobulin $\mathrm{G}$ antibody directed against the $\alpha$-subunit of the interleukin- 2 receptor (CD25), which is expressed on several immune cells. In the Phase II CHOICE study, add-on daclizumab together with interferon-beta reduced the number of new or enlarged gadolinium-enhancing lesions compared with interferonbeta alone. ${ }^{89}$

The Phase IIb SELECT study showed a significant reduction in the annualized relapse rate by $50 \%$ in the $300 \mathrm{mg}$ dose arm and $54 \%$ in the $150 \mathrm{mg}$ dose arm, and of disease activity on magnetic resonance imaging, as measured by number of new gadolinium-enhancing and new or newly enlarging hyperintense $\mathrm{T} 2$ lesions in patients with relapsingremitting MS treated with daclizumab as compared with placebo. ${ }^{90}$ The Phase III DECIDE study comparing the efficacy and safety of daclizumab with interferon-beta 1a in patients with relapsing-remitting MS is currently ongoing. ${ }^{91}$

\section{Stem cell therapy}

In the past few years, case reports and results of small, openlabel, nonrandomized Phase I and II studies on hematopoietic and mesenchymal stem cell transplantation mainly in relapsing forms of MS were reported..$^{92-97}$ Until now, there have not been any Phase III studies on stem cell therapy in MS, although the first randomized, open-label Phase III study on hematopoietic stem cell transplantation is currently recruiting patients. ${ }^{98}$ Large randomized controlled trials are needed to evaluate whether stem cell transplantation is more efficacious than the commonly used MS drugs and outweighs the risk of transplantation-related mortality.

\section{Outlook}

During the last two decades, a number of drugs have been approved for the treatment of MS. All drugs significantly reduce relapse rates, and some have profound effects on disease progression, even during the first years of treatment. However, the increasing efficacy of MS therapies has been accompanied by new and sometimes life-threatening side effects. During the next decade, a number of new drugs will become available for the treatment of relapsing-remitting MS and clinically isolated syndrome. With the increasing number of drugs, safety will become a key issue, especially for baseline therapies. Unfortunately, the safest drugs are also those with the lowest efficacy. We expect that an increase in specificity by selectively targeting particular immune cells that are deeply involved in the disease pathogenesis will eventually pave the way for safe and efficacious drugs for use in clinically isolated syndrome and relapsing-remitting MS. Moreover, treatments that impact on the course of primary and secondary progressive MS are desperately needed. Accordingly, a number of trials have been initiated that will hopefully result in better treatment of these entities. In the long run, a better understanding of the pathogenesis involved is essential to develop highly specific and effective MS therapies that do not have severe side effects.

\section{Disclosure}

$\mathrm{BH}$ and his Department of Neurology have received invitational financial support for research activities from Bayer Healthcare Pharmaceuticals, Biogen Idec, Merck Serono, Novartis, Metanomics, Protagen, and Roche, and fees or honoraria for consulting from Bayer Healthcare Pharmaceuticals, Biogen Idec, Genzyme, Merck Serono, Novartis, Teva Pharmaceuticals, GlaxoWellcome, Chugai Pharmaceuticals, and Sanofi-aventis. RCS has no conflicts of interest to report in this work.

\section{References}

1. Multiple Sclerosis International Federation. Atlas of MS Database. Available from: http://www.atlasofms.org. Accessed September 19, 2012.

2. Sadovnick AD, Ebers GC, Dyment DA, Risch NJ. Evidence for genetic basis of multiple sclerosis. The Canadian Collaborative Study Group. Lancet. 1996;347:1728-1730.

3. Ascherio A, Munger KL. Environmental risk factors for multiple sclerosis. Part I: the role of infection. Ann Neurol. 2007;61:288-299.

4. Ascherio A, Munger KL. Environmental risk factors for multiple sclerosis. Part II: noninfectious factors. Ann Neurol. 2007;61:504-513.

5. Sawcer S, Hellenthal G, Pirinen M, et al. Genetic risk and a primary role for cell-mediated immune mechanisms in multiple sclerosis. Nature. 2011;476:214-219.

6. Ascherio A, Munger KL, Simon KC. Vitamin D and multiple sclerosis. Lancet Neurol. 2010;9:599-612.

7. Hughes LE, Smith PA, Bonell S, et al. Cross-reactivity between related sequences found in Acinetobacter sp, Pseudomonas aeruginosa, myelin basic protein and myelin oligodendrocyte glycoprotein in multiple sclerosis. J Neuroimmunol. 2003;144:105-115.

8. Swanborg RH, Whittum-Hudson JA, Hudson AP. Infectious agents and multiple sclerosis - are Chlamydia pneumoniae and human herpes virus 6 involved? J Neuroimmunol. 2003;136:1-8.

9. Hemmer B, Archelos JJ, Hartung HP. New concepts in the immunopathogenesis of multiple sclerosis. Nat Rev Neurosci. 2002;3: 291-301. 
10. Fujinami RS, Oldstone MB. Amino acid homology between the encephalitogenic site of myelin basic protein and virus: mechanism for autoimmunity. Science. 1985;230:1043-1045.

11. Aichele P, Bachmann MF, Hengartner H, Zinkernagel RM. Immunopathology or organ-specific autoimmunity as a consequence of virus infection. Immunol Rev. 1996;152:21-45.

12. Wucherpfennig KW, Strominger JL. Molecular mimicry in T cellmediated autoimmunity: viral peptides activate human $\mathrm{T}$ cell clones specific for myelin basic protein. Cell. 1995;80:695-705.

13. O'Connor KC, Bar-Or A, Hafler DA. The neuroimmunology of multiple sclerosis: possible roles of $\mathrm{T}$ and $\mathrm{B}$ lymphocytes in immunopathogenesis. J Clin Immunol. 2001;21:81-92.

14. Gay FW, Drye TJ, Dick GW, Esiri MM. The application of multifactorial cluster analysis in the staging of plaques in early multiple sclerosis. Identification and characterization of the primary demyelinating lesion. Brain. 1997;120 Pt 8:1461-1483.

15. Hauser SL, Bhan AK, Gilles F, Kemp M, Kerr C, Weiner HL. Immunohistochemical analysis of the cellular infiltrate in multiple sclerosis lesions. Ann Neurol. 1986;19:578-587.

16. Lucchinetti C, Bruck W, Parisi J, Scheithauer B, Rodriguez M, Lassmann $\mathrm{H}$. Heterogeneity of multiple sclerosis lesions: implications for the pathogenesis of demyelination. Ann Neurol. 2000;47: $707-717$.

17. Ferguson B, Matyszak MK, Esiri MM, Perry VH. Axonal damage in acute multiple sclerosis lesions. Brain. 1997;120 Pt 3:393-399.

18. Bruck W, Kuhlmann T, Stadelmann C. Remyelination in multiple sclerosis. J Neurol Sci. 2003;206:181-185.

19. Lassmann H, Bruck W, Lucchinetti C, Rodriguez M. Remyelination in multiple sclerosis. Mult Scler. 1997;3:133-136.

20. Barnett MH, Prineas JW. Relapsing and remitting multiple sclerosis: pathology of the newly forming lesion. Ann Neurol. 2004;55: $458-468$.

21. Sakaguchi S. Naturally arising Foxp3-expressing CD25+CD4+ regulatory $\mathrm{T}$ cells in immunological tolerance to self and non-self. Nat Immunol. 2005;6:345-352.

22. Hvilsted Nielsen H, Toft-Hansen H, Lambertsen KL, Owens T, Finsen B. Stimulation of adult oligodendrogenesis by myelin-specific T cells. Am J Pathol. 2011;179:2028-2041.

23. Neumann H, Medana IM, Bauer J, Lassmann H. Cytotoxic T lymphocytes in autoimmune and degenerative CNS diseases. Trends Neurosci. 2002;25:313-319.

24. Tuohy VK, Yu M, Weinstock-Guttman B, Kinkel RP. Diversity and plasticity of self recognition during the development of multiple sclerosis. J Clin Invest. 1997;99:1682-1690.

25. Uccelli A, Aloisi F, Pistoia V. Unveiling the enigma of the CNS as a B-cell fostering environment. Trends Immunol. 2005;26:254-259.

26. Storch MK, Piddlesden S, Haltia M, Iivanainen M, Morgan P, Lassmann H. Multiple sclerosis: in situ evidence for antibody- and complement-mediated demyelination. Ann Neurol. 1998;43:465-471.

27. Srivastava R, Aslam M, Kalluri SR, et al. Potassium channel KIR4.1 as an immune target in multiple sclerosis. $N$ Engl J Med. 2012;367: $115-123$.

28. Morandi B, Bramanti P, Bonaccorsi I, et al. Role of natural killer cells in the pathogenesis and progression of multiple sclerosis. Pharmacol Res. 2008;57:1-5.

29. Colombo M, Dono M, Gazzola P, et al. Accumulation of clonally related B lymphocytes in the cerebrospinal fluid of multiple sclerosis patients. J Immunol. 2000;164:2782-2789.

30. Keegan M, Konig F, McClelland R, et al. Relation between humoral pathological changes in multiple sclerosis and response to therapeutic plasma exchange. Lancet. 2005;366:579-582.

31. Howell OW, Reeves CA, Nicholas R, et al. Meningeal inflammation is widespread and linked to cortical pathology in multiple sclerosis. Brain. 2011;134:2755-2771.

32. Lucchinetti CF, Popescu BF, Bunyan RF, et al. Inflammatory cortical demyelination in early multiple sclerosis. $N$ Engl $J$ Med. 2011;365: 2188-2197.
33. [No authors listed]. Interferon beta- $1 \mathrm{~b}$ is effective in relapsing-remitting multiple sclerosis. I. Clinical results of a multicenter, randomized, double-blind, placebo-controlled trial. The IFNB Multiple Sclerosis Study Group. Neurology. 1993;43:655-661.

34. [No authors listed]. Placebo-controlled multicentre randomised trial of interferon-beta- $1 \mathrm{~b}$ in treatment of secondary progressive multiple sclerosis. European Study Group on interferon-beta-1b in secondary progressive MS. Lancet. 1998;352:1491-1497.

35. Panitch H, Miller A, Paty D and Weinshenker B, North American Study Group on Interferon beta-1b in Secondary Progressive MS. Interferon beta-1b in secondary progressive MS: results from a 3-year controlled study. Neurology. 2004;63:1788-1795.

36. Kappos L, Weinshenker B, Pozzilli C, et al. Interferon beta- $1 \mathrm{~b}$ in secondary progressive MS: a combined analysis of the two trials. Neurology. 2004;63:1779-1787.

37. Jacobs LD, Beck RW, Simon JH, et al. Intramuscular interferon-beta-1a therapy initiated during a first demyelinating event in multiple sclerosis. CHAMPS Study Group. N Engl J Med. 2000;343:898-904.

38. Kappos L, Polman CH, Freedman MS, et al. Treatment with interferonbeta- $1 \mathrm{~b}$ delays conversion to clinically definite and McDonald MS in patients with clinically isolated syndromes. Neurology. 2006;67: $1242-1249$

39. Ann Marrie R, Rudick RA. Drug insight: interferon treatment in multiple sclerosis. Nat Clin Pract Neurol. 2006;2:34-44.

40. Chen M, Chen G, Deng S, Liu X, Hutton GJ, Hong J. IFN-beta induces the proliferation of CD4+CD25+Foxp3+ regulatory $\mathrm{T}$ cells through upregulation of GITRL on dendritic cells in the treatment of multiple sclerosis. J Neuroimmunol. 2012;242:39-46.

41. Teitelbaum D, Webb C, Bree M, Meshorer A, Arnon R, Sela M. Suppression of experimental allergic encephalomyelitis in Rhesus monkeys by a synthetic basic copolymer. Clin Immunol Immunopathol. 1974;3:256-262.

42. Teitelbaum D, Aharoni R, Arnon R, Sela M. Specific inhibition of the T-cell response to myelin basic protein by the synthetic copolymer Cop 1. Proc Natl Acad Sci U SA. 1988;85:9724-9728.

43. Gran B, Tranquill LR, Chen M, et al. Mechanisms of immunomodulation by glatiramer acetate. Neurology. 2000;55:1704-1714.

44. Teitelbaum D, Fridkis-Hareli M, Arnon R, Sela M. Copolymer 1 inhibits chronic relapsing experimental allergic encephalomyelitis induced by proteolipid protein (PLP) peptides in mice and interferes with PLPspecific T cell responses. J Neuroimmunol. 1996;64:209-217.

45. Ben-Nun A, Mendel I, Bakimer R, et al. The autoimmune reactivity to myelin oligodendrocyte glycoprotein (MOG) in multiple sclerosis is potentially pathogenic: effect of copolymer 1 on MOG-induced disease. J Neurol. 1996;243:S14-S22.

46. Johnson KP, Brooks BR, Cohen JA, et al. Copolymer 1 reduces relapse rate and improves disability in relapsing-remitting multiple sclerosis: results of a Phase III multicenter, double-blind placebo-controlled trial. The Copolymer 1 Multiple Sclerosis Study Group. Neurology. 1995;45: $1268-1276$

47. Comi G, Filippi M, Wolinsky JS. European/Canadian multicenter, double-blind, randomized, placebo-controlled study of the effects of glatiramer acetate on magnetic resonance imaging - measured disease activity and burden in patients with relapsing multiple sclerosis. European/Canadian Glatiramer Acetate Study Group. Ann Neurol. 2001;49:290-297.

48. Comi G, Martinelli V, Rodegher M, et al. Effect of glatiramer acetate on conversion to clinically definite multiple sclerosis in patients with clinically isolated syndrome (PreCISe study): a randomised, doubleblind, placebo-controlled trial. Lancet. 2009;374:1503-1511.

49. Lalive PH, Neuhaus O, Benkhoucha M, et al. Glatiramer acetate in the treatment of multiple sclerosis: emerging concepts regarding its mechanism of action. CNS Drugs. 2011;25:401-414.

50. Haas J, Korporal M, Balint B, Fritzsching B, Schwarz A, Wildemann B. Glatiramer acetate improves regulatory T-cell function by expansion of naive CD4(+)CD25(+)FOXP3(+)CD31(+) T-cells in patients with multiple sclerosis. J Neuroimmunol. 2009;216:113-117. 
51. Hong J, Li N, Zhang X, Zheng B, Zhang JZ. Induction of CD4+CD25+ regulatory $T$ cells by copolymer-I through activation of transcription factor Foxp3. Proc Natl Acad Sci U SA. 2005;102: 6449-6454.

52. Hartung HP, Gonsette R, Konig N, et al. Mitoxantrone in progressive multiple sclerosis: a placebo-controlled, double-blind, randomised, multicentre trial. Lancet. 2002;360:2018-2025.

53. Bielekova B, Becker BL. Monoclonal antibodies in MS: mechanisms of action. Neurology. 2010;74 Suppl 1:S31-S40.

54. Polman $\mathrm{CH}$, O'Connor PW, Havrdova E, et al. A randomized, placebo-controlled trial of natalizumab for relapsing multiple sclerosis. N Engl J Med. 2006;354:899-910.

55. Rudick RA, Stuart WH, Calabresi PA, et al. Natalizumab plus interferon-beta-1a for relapsing multiple sclerosis. N Engl J Med. 2006; 354:911-923.

56. Bloomgren G, Richman S, Hotermans C, et al. Risk of natalizumabassociated progressive multifocal leukoencephalopathy. $N$ Engl J Med. 2012;366:1870-1880.

57. O'Connor PW, Goodman A, Kappos L, et al. Disease activity return during natalizumab treatment interruption in patients with multiple sclerosis. Neurology. 2011;76:1858-1865.

58. Brinkmann V, Billich A, Baumruker T, et al. Fingolimod (FTY720): discovery and development of an oral drug to treat multiple sclerosis. Nat Rev Drug Discov. 2010;9:883-897.

59. Kowarik MC, Pellkofer HL, Cepok S, et al. Differential effects of fingolimod (FTY720) on immune cells in the CSF and blood of patients with MS. Neurology. 2011;76:1214-1221.

60. Cohen JA, Barkhof F, Comi G, et al. Oral fingolimod or intramuscular interferon for relapsing multiple sclerosis. N Engl J Med. 2010;362: $402-415$

61. Kappos L, Radue EW, O'Connor P, et al. A placebo-controlled trial of oral fingolimod in relapsing multiple sclerosis. NEngl J Med. 2010;362: 387-401.

62. European Medicines Agency. European Medicines Agency gives new advice to better manage risk of adverse effects on the heart with Gilenya. Available from: http://www.ema.europa.eu/ema/index.jsp?curl=pages/ medicines/human/public_health_alerts/2012/04/human_pha_ detail_000059.jsp\&mid=WC0b01ac058001d126. Accessed September 15, 2012.

63. US Food and Drug Administration. FDA Drug Safety Communication: revised recommendations for cardiovascular monitoring and use of multiple sclerosis drug Gilenya (fingolimod). Available from: http://www.fda.gov/Drugs/DrugSafety/ucm303192.htm. Accessed September 15, 2012.

64. Jones JL, Coles AJ. Campath-1H treatment of multiple sclerosis. Neurodegener Dis. 2008;5:27-31.

65. Coles AJ, Compston DA, Selmaj KW, et al. Alemtuzumab versus interferon-beta-1a in early multiple sclerosis. N Engl J Med. 2008;359: 1786-1801.

66. Cohen JA, Coles AJ, Arnold DL, et al; CARE-MS I investigators. Alemtuzumab versus interferon-beta 1a as first-line treatment for patients with relapsing-remitting multiple sclerosis: a randomised controlled Phase 3 trial. Lancet. 2012;380:1819-1828.

67. Coles AJ, Twyman CL, Arnold DL, et al; CARE-MS II investigators. Alemtuzumab for patients with relapsing multiple sclerosis after disease-modifying therapy: a randomised controlled Phase 3 trial. Lancet. 2012;380:1829-1839.

68. Hauser SL, Waubant E, Arnold DL, et al. B-cell depletion with rituximab in relapsing-remitting multiple sclerosis. $N$ Engl J Med. 2008;358: 676-688

69. Hawker K, O'Connor P, Freedman MS, et al. Rituximab in patients with primary progressive multiple sclerosis: results of a randomized double-blind placebo-controlled multicenter trial. Ann Neurol. 2009;66: 460-471.

70. Kappos L, Li D, Calabresi PA, et al. Ocrelizumab in relapsingremitting multiple sclerosis: a Phase 2, randomised, placebo-controlled, multicentre trial. Lancet. 2011;378:1779-1787.
71. ClinicalTrials.gov. A study of ocrelizumab in comparison with interferon beta-1a (Rebif) in patients with relapsing multiple sclerosis. Available from: http://www.clinicaltrials.gov/show/NCT01247324 and http:// www.clinicaltrials.gov/show/NCT01412333. Accessed September 23, 2012.

72. ClinicalTrials.gov. A study of ocrelizumab in patients with primary progressive multiple sclerosis. Available from: http://www.clinicaltrials. gov/show/NCT01194570. Accessed September 23, 2012.

73. Soelberg Sorensen P, Drulovic J, Havrdova E, Lisby S, Graff O, Shackelford S. Magnetic resonance imaging (MRI) efficacy of ofatumumab in relapsing-remitting multiple sclerosis (RRMS) 24-week results of a Phase II study [abstract]. Mult Scler. 2010; 16 Suppl 10:S37-S38.

74. Zou LP, Abbas N, Volkmann I, et al. Suppression of experimental autoimmune neuritis by ABR-215062 is associated with altered Th1/Th2 balance and inhibited migration of inflammatory cells into the peripheral nerve tissue. Neuropharmacology. 2002;42: 731-739.

75. Brunmark C, Runstrom A, Ohlsson L, et al. The new orally active immunoregulator laquinimod (ABR-215062) effectively inhibits development and relapses of experimental autoimmune encephalomyelitis. J Neuroimmunol. 2002;130:163-172.

76. Comi G, Pulizzi A, Rovaris M, et al. Effect of laquinimod on MRImonitored disease activity in patients with relapsing-remitting multiple sclerosis: a multicentre, randomised, double-blind, placebo-controlled Phase IIb study. Lancet. 2008;371:2085-2092.

77. Comi G, Jeffery D, Kappos L, et al. Placebo-controlled trial of oral laquinimod for multiple sclerosis. $N$ Engl J Med. 2012;366: $1000-1009$.

78. ClinicalTrials.gov. BRAVO study: laquinimod double blind placebo controlled study in RRMS patients with a rater blinded reference arm of interferon $\beta-1 \mathrm{a}\left(\right.$ Avonex $\left.^{\mathbb{}}\right)$. Available from: http://clinicaltrials.gov/ show/NCT00605215. Accessed September 17, 2012.

79. Wilms H, Sievers J, Rickert U, Rostami-Yazdi M, Mrowietz U, Lucius R. Dimethylfumarate inhibits microglial and astrocytic inflammation by suppressing the synthesis of nitric oxide, IL-1beta, TNF-alpha and IL-6 in an in-vitro model of brain inflammation. J Neuroinflammation. 2010;7:30

80. Kappos L, Gold R, Miller DH, et al. Efficacy and safety of oral fumarate in patients with relapsing-remitting multiple sclerosis: a multicentre, randomised, double-blind, placebo-controlled Phase IIb study. Lancet. 2008;372:1463-1472.

81. Fox RJ, Miller DH, Phillips JT, et al. Placebo-controlled Phase 3 study of oral BG-12 or glatiramer in multiple sclerosis. $N$ Engl $J$ Med. 2012;367:1087-1097.

82. Gold R, Kappos L, Arnold DL, et al. Placebo-controlled Phase 3 study of oral BG-12 for relapsing multiple sclerosis. $N$ Engl J Med. 2012;367:1098-1107.

83. Schorlemmer HU, Milbert U, Zeitter D, Haun G, Wunschel M, Bartlett RR. Cell cycle regulation and inhibition of de novo pyrimidine biosynthesis by leflunomide. Inflamm Res. 1999;48 Suppl 2: S115-S116.

84. O'Connor P, Wolinsky JS, Confavreux C, et al. Randomized trial of oral teriflunomide for relapsing multiple sclerosis. N Engl J Med. 2011;365: 1293-1303.

85. Kappos L, Comi G, Confavreux C, et al. The efficacy and safety of teriflunomide in patients with relapsing MS: results from TOWER, a Phase III, placebo-controlled study. Abstract presented at the 28th Congress of the European Committee for Treatment and Research in Multiple Sclerosis, October 10-13, 2012, Lyon, France.

86. ClinicalTrials.gov. An Efficacy Study of Teriflunomide in Patients with Relapsing Multiple Sclerosis (TOWER). Available from: http:// clinicaltrials.gov/show/NCT00751881. Accessed September 17, 2012.

87. ClinicalTrials.gov. A study comparing the effectiveness and safety of Teriflunomide and Interferon Beta-1a in Patients with Relapsing Multiple Sclerosis (TENERE). Available from: http://clinicaltrials.gov/ show/NCT00883337. Accessed September 17, 2012. 
88. ClinicalTrials.gov. Phase III study with Teriflunomide Versus Placebo in Patients with First Clinical Symptom of Multiple Sclerosis (TOPIC). Available from: http://clinicaltrials.gov/show/NCT00622700. Accessed September 17, 2012.

89. Wynn D, Kaufman M, Montalban X, et al. Daclizumab in active relapsing multiple sclerosis (CHOICE study): a Phase 2, randomised, double-blind, placebo-controlled, add-on trial with interferon-beta. Lancet Neurol. 2010;9:381-390.

90. Giovannoni G, Gold R, Selmaj K, et al. A randomized, doubleblind, placebo-controlled study to evaluate the safety and efficacy of daclizumab HYP monotherapy in relapsing-remitting multiple sclerosis: primary results of the SELECT trial. Abstract presented at the 5th Joint triennial congress of the European and Americas Committees for Treatment and Research in Multiple Sclerosis, October 19-22, 2011, Amsterdam, The Netherlands.

91. ClinicalTrials.gov. Efficacy and Safety of Daclizumab High Yield Process Versus Interferon $\beta$ 1a in Patients with Relapsing-Remitting Multiple Sclerosis (DECIDE). Available from: http://clinicaltrials.gov/ show/NCT01064401. Accessed September 17, 2012.

92. Connick P, Kolappan M, Crawley C, et al. Autologous mesenchymal stem cells for the treatment of secondary progressive multiple sclerosis: an open-label Phase 2a proof-of-concept study. Lancet Neurol. 2012;11: $150-156$.
93. Nash RA, Hutton GJ, Racke MK, et al. Treatment of severe relapsing-remitting multiple sclerosis with high-dose immunosuppressive therapy and autologous hematopoietic cell transplantation: early results of the HALT MS clinical trial (Immune Tolerance Network: ITN033AI). ASH Annual Meeting Abstracts. 2011;118:3075.

94. Burt RK, Loh Y, Cohen B, et al. Autologous non-myeloablative haemopoietic stem cell transplantation in relapsing-remitting multiple sclerosis: a Phase I/II study. Lancet Neurol. 2009;8:244-253.

95. Mancardi GL, Murialdo A, Rossi P, et al. Autologous stem cell transplantation as rescue therapy in malignant forms of multiple sclerosis. Mult Scler. 2005;11:367-371.

96. Kimiskidis V, Sakellari I, Tsimourtou V, et al. Autologous stem-cell transplantation in malignant multiple sclerosis: a case with a favorable long-term outcome. Mult Scler. 2008;14:278-283.

97. Fagius J, Lundgren J, Oberg G. Early highly aggressive MS successfully treated by hematopoietic stem cell transplantation. Mult Scler. 2009;15: 229-237.

98. ClinicalTrials.gov. Hematopoietic stem cell therapy for patients with inflammatory multiple sclerosis failing interferon: a randomized study. Available from: http://clinicaltrials.gov/show/NCT00273364. Accessed January 14, 2013.

\section{Publish your work in this journal}

ImmunoTargets and Therapy is an international, peer-reviewed open access journal focusing on the immunological basis of diseases, potential targets for immune based therapy and treatment protocols employed to improve patient management. Basic immunology and physiology of the immune system in health, and disease will be also covered. In addition, the journal will focus on the impact of manage-

\section{Dovepress}

ment programs and new therapeutic agents and protocols on patient perspectives such as quality of life, adherence and satisfaction. The manuscript management system is completely online and includes a very quick and fair peer-review system, which is all easy to use. Visit http://www.dovepress.com/testimonials.php to read real quotes from published authors. 